\title{
Stock Market and Economic Growth in Ghana, Kenya and Nigeria
}

\author{
Ifuero Osad Osamwonyi ${ }^{1} \&$ Abudu Kasimu ${ }^{1}$ \\ ${ }^{1}$ Department of Banking and Finance, University of Benin, Benin, Nigeria \\ Correspondence: Ifuero Osad Osamwonyi, Department of Banking and Finance, University of Benin, Benin, Edo \\ State, Nigeria. Tel: 234-802-332-3968. E-mail: ifueroosad@yahoo.co.uk
}

Received: January 29, 2013

Accepted: March 13, $2013 \quad$ Online Published: April 8, 2013

doi:10.5430/ijfr.v4n2p83

URL: http://dx.doi.org/10.5430/ijfr.v4n2p83

\begin{abstract}
In the paper, we examine the causal relationship and the direction of causality between stock market development and economic growth in Ghana, Kenya and Nigeria. In examining the causal relationship and the direction of causality, we used the Granger Causality test procedure as developed in Granger. The study regressed five indicators of stock market namely stock market capitalization (MC), stock turnover ratio (STO), stock traded value (TVL), number of listed securities (LS), and stock market index (MI) against the real gross domestic product (GDP) which is used as a proxy for economic growth.

Using the 1989 - 2009 data sets, the empirical findings of the study show that there is no causal relationship between stock market development and economic growth in Ghana and Nigeria, but revealed a bidirectional causal relationship between stock market development and economic growth in Kenya. When MC was used as a proxy for stock market development, MC and LS were found to Granger cause economic growth. Bidirectional causality was found between STO and GDP. TVL was found to have a strong negative effect on GDP. Based on the results of the study, we recommend that policy makers and regulatory bodies should formulate and implement policies that will attract investors and avail the real sector of the economy the much needed fund for production and encourage listing of companies that contribute largely to GDP in the nation stock exchange.
\end{abstract}

Keywords: stock market, economic growth, granger causality test

\section{Introduction}

The use of stock market Indicator for the prediction of future economic growth or vice versa has been a debatable issue in finance and economics. It is commonly believed that large decreases in stock prices are reflective of future recession, and increasing stock prices are leading indicators of future economic growth (Mun, Siong \& Thing, 2008). For instance, the uncertainty embedded in the recession of 2009 triggered a large-scale drop in stock prices that was reflected in the Dow Jones and the S\&P 500 (Fuentes, 2010).

Stock market has been associated with economic growth through its role as sources for new private capital. On the other hand, economic growth may be the catalyst for stock market growths. According to Osamwonyi (2005:4), "a stock exchange is an arrangement for trading financial securities and where one can raise long-term capital. It seeks the efficient allocation of available capital funds to the diverse uses in the economy and through its extreme sensitive pricing mechanism, ensures that the available capital resources are allocated to firms with competitive returns". Stock markets are seen as enhancing the operations of the domestic financial system in general and the capital market in particular (Kenny \& Moss, 1998). According to Yartey \& Adjasi, (2007) and Singh, (1997), the establishment of stock markets in Africa is expected to boost domestic savings and increase the quantity and quality of investment.

African Stock Markets are really no more than equity exchanges as the bond markets are essentially non-existent (Osaze, 2007). Over 50\% of 54 African countries operate stock exchanges. The rapid expansion of these stock exchanges in the continent has contributed to economic development in various ways such as facilitating long term capital mobilization, the provision of alternative investment opportunities, attracting foreign capital inflows and serving as a signal of economic performance (Kumo, 2009). Well functioning stock markets, along with well-designed institutions and regulatory systems will foster economic growth.

The principal channel for the linkage between stock market development and economic performance is liquidity provision of the market (Senbet \& Otchere, 2008). Yartey \& Adjasi (2007) found out that, stock markets contribute to financing of corporate investments and hence growth of listed firms in Africa as they are required to keep best practices. 
This shows that corporate financing channel is another mechanism for the stock markets to impact aggregate economic performance (Senbet \& Otchere, 2008). Empirical findings indicate that economic growth increases relative to the rest of the world after a stock exchange opens. Mohtadi \& Agarwal (2004) examine the link between stock market development and economic growth in developing countries, using a Panel data approach that covers 21 emerging markets over 21 years (1977-1997), they find that turnover ratio is an important and statistically significant determinant of investments by firms and that these investments are in turn significant determinants of aggregate growth. Foreign Direct Investment (FDI) is also found to have a strong positive influence on aggregate growth (Ogunkola, Bankole, \& Adewuyi, 2006).

Stock market activities play a major role in determining the level of economic activities in both emerging and developed economies, by providing and efficiently allocating capital for investment, providing appropriate platform to engender best corporate practices that will result in growing investment and further growth of the economy. What may not be clear is whether there is a long-run bidirectional causality between financial development and economic growth or not. Another grey area is the relationship between stock market indicators and the proxy for economic growth (real gross domestic product) in the emerging economies. Other studies show that while there is some consensus on the positive relationship between stock market development and economic growth, there is also disagreement on the direction of causal relationship with some suggesting that it is from finance to economic growth and others suggesting the opposite that the link is bidirectional. Some contend that there is no link between stock market development and economic development (Sililo, 2010). However, the causal relationship between the indicators of stock market development and economic growth in the developing countries is still a thing of controversy particularly in the Sub-Saharan region. Some critics of stock market integration point out that some exchanges in Africa are mere national status in that the supposed effect of their existence is not felt in the economy and that some exchanges stems from external influence rather than local demand (UNECA, 2006). In the light of this, we seek to find out, a causality relation between stock market development and economic growth in Ghana, Kenya and Nigeria.

The study investigated causal relationship between stock market development and economic growth in Ghana, Kenya and Nigeria. Specifically, the study investigated:

- if there is a causal relationship between stock market development and economic growth in Ghana, Kenya and Nigeria; and also

- determine the direction of flow of causality between stock market development and economic growth in Ghana, Kenya and Nigeria.

The two hypotheses are:

$\mathrm{H}_{\mathrm{ol}}$ : There is no causal relationship between stock market development and economic growth

The second hypothesis states that:

$\mathrm{H}_{\mathrm{o} 2}$ : The direction of causality link between stock market development and economic growth does not flow from stock market development to economic growth and vise versa.

The study employed data of three African countries which are among the leading emerging stock markets: Ghana, Kenya, and Nigeria to see the causal relationship between stock market indicators and economic growth. These data cover a period of twenty-one years, between 1989 and 2009. The choice of this period was informed by macroeconomic reforms, economic boom and the global financial crisis (meltdown).

Many studies have been done in this area, however this study has added to the stock of knowledge with empirical validation from the emerging economies. This study also verifies existing theories on the link between stock markets and economic growth and highlighted the specific roles of major indicators of the capital market, which are relevant in testing the capital market-economic growth linkages. It also deals with issues of unmeasured cross country heterogeneity, causality, dynamics and endogeneity which are elements that have been relatively ignored in the literature of growth modelling; examining the complex linkages between stock market development, institutional bottlenecks and economic growth. The special importance of settling the issue of causality in developing countries also provides policy makers with insights to determine areas of most urgent reform.

\section{Literature Review}

According to Saint-Paul (1992) in Alovsat (1998), stock exchanges contribute to economic growth through the global risk diversification opportunities they offer. Generally, stock market is expected to accelerate economic growth by providing a boost to domestic savings and increasing the quantity and quality of investment (Singh, 1997). The stock market stimulates economic growth through savings amongst individual, providing avenue for business financing and 
efficient allocation of resources in the economy. One of the most fundamental strategies of economic growth is simply to increase the proportion of national income saved. If we can raise savings we can increase the rate of GDP growth (Todaro \& Smith, 2009). Foreign direct investment (FDI) is another channel through which foreign technology permeates domestic economy. (Ogunkola, Bankole, \& Adewuyi, 2006). The stock market generates efficient information about the performance of firms, reflecting the fundamentals in the real sector. The indicators of the performance of the stock markets are market capitalization, trading value, turnover ratio and many more. In a study by Levine \& Zervos (1996) where they used composite index combining volume, liquidity, and diversification indicators for stock exchange and the real growth rate in per capita GDP as economic growth indicator found that a very strong positive correlation exist between stock market development and economic growth.

Some of the studies on the link between stock market development and economic growth include: Korajczyk (1996); Levine \& Zervos (1996); Levine \& Zervos (1998); Filer et al (1999); Rousseau \& Wachtel (2000); Beck \& Levine (2001); Miner (2003); Rioja \& Valev (2004); Caporale, Howell, \& Soliman (2004); \& N'Zue (2006) amongst others. Filer et al finds that an active equity market is an important engine of economic growth in developing countries. When Caporale et al (2004) examined the causal link between stock market development, financial development and economic growth in seven countries; they found that a well developed stock market can foster growth in the long-run. Odhiambo (2010) used the Auto-Regressive Distributed Lag (ARDL-Bound) testing approach to relate three proxies of stock market development namely (stock market capitalization, stock market traded value, and stock market turnover) with real GDP per capita, a proxy for economic growth. The result was that causal relationship between stock market development and economic growth is sensitive to the proxy used for measuring the stock market development.

Also, a study conducted in Nepal by Bahadur \& Neupane (2006) revealed that the stock market growth and economic growth have long-run relationship. It also revealed that the stock market fluctuation do help to predict the future economy. Osinubi (1998) discovered the contrary, that the effect of stock market on economic growth is weak and insignificant. In a study by Donwa \& Odia (2010), they found that market capitalization and value of transaction had positive but insignificant impact on the GDP whereas the total new issues had a negative influence on GDP. Salisu \& Ajide (2010) also found that stock market development causes growth as consistent with the findings of Mohtadi \& Agarwal (2004), and Oke (2005). They discover that the direction of causality is from market capitalization to economic growth and also that there is no causal linkage between total value traded ratio and economic growth. While a bidirectional causality was found between turnover ratio and economic growth.

Capasso (2006) using a sample of 24 advanced Organization for Economic Cooperation and Development (OECD) and some emerging economies investigates the linkage between stock market development and economic growth covering the period 1988-2002. The finding shows a strong and positive correlation between stock market development and economic growth and later concludes that stock markets tend to emerge and develop only when economies reach a reasonable size and with high level of capital accumulation.

Singh (1997) utilizes time series data for India to examine the relationship between financial development and economic growth for the period 1951-1952 to 1995-1996. Using Bivariate Vector Autoregressive (VAR), impulse responses and variance decomposition, their results suggest the existence of bidirectional Causality between financial development and economic growth.

\section{Method and Data}

The data set employed in this study consists of annual data from three African countries - Ghana, Kenya and Nigeria. The research variables derived from the literature discussed so far are stock market capitalization, stock turnover ratio, number of listed security, traded value, stock market index, and real gross domestic product. These were used as indicators of the stock market growth, and the proxy for economic growth. The data for the study were sourced from Securities and Exchange Commission's Annual Reports and Statistical Bulletin of Nigeria and Ghana, Capital Market Authority of Kenya, African Securities Exchanges Association's (ASEA) Annual Reports of various years, Data Bank group data base, World Federation Exchange data base, various years annual reports of relevant stock exchanges, World Bank development indicators data set, Central Banks of relevant countries, journals and other publications. The indicators of stock market development used for the test include market capitalization ratio, total value traded, and turnover, number of listed security and stock market index. While the growth rate of gross domestic product was used as a proxy for economic growth.

The model was based on those of past studies; Demirgue-Kunt \& Levine (1996), Levine \& Zervos (1996), Demirgue-Kunt et al (1996), Cudi Tuncer \& Alovsat (2001), Ariyo \& Adelegan (2005), Osamwonyi, (2005), Ewah et al (2009), Donwa \& Odia (2010) who have investigated the linkage between stock market development and economic growth. The model is as follows: 


$$
\mathrm{GDP}=\mathrm{f}(\mathrm{MC}, \mathrm{TVL}, \mathrm{STO}, \mathrm{LS}, \mathrm{MI})
$$

Where:

$$
\begin{array}{ll}
\text { GDP } & \quad=\text { Real Gross Domestic Product, } \\
\text { MC } & =\text { Stock Market Capitalization, } \\
\text { TVL } & =\text { Value Traded, } \\
\text { STO } & =\text { Turnover Ratio, } \\
\text { LS } & =\text { Number of Listed Securities, } \\
\text { MI } & =\text { Stock Market Index. } \\
\alpha_{0} \ldots \alpha_{6} & =\text { Parameters } \\
\mathrm{t} & =\text { Current Period }
\end{array}
$$

\section{Model 1}

This model specify the equation for Nigeria

$$
\mathrm{GDP}_{\mathrm{tN}}=\alpha_{0}+\alpha_{1} \mathrm{GDP}_{\mathrm{t}-1}+\alpha_{2} \mathrm{MC}_{\mathrm{t}}+\alpha_{3} \mathrm{TVL}_{\mathrm{t}}+\alpha_{4} \mathrm{STO}_{\mathrm{t}}+\alpha_{5} \mathrm{LS}_{\mathrm{t}}+\alpha_{6} \mathrm{MI}_{\mathrm{t}}+\mathrm{e}
$$

The variables and parameter above are defined with regards to Nigeria.

Model 2

$$
\mathrm{GDP}_{\mathrm{tG}}=\alpha_{0}+\alpha_{1} \mathrm{GDP}_{\mathrm{t}-1}+\alpha_{2} \mathrm{MC}_{\mathrm{t}}+\alpha_{3} \mathrm{TVL}_{\mathrm{t}}+\alpha_{4} \mathrm{STO}_{\mathrm{t}}+\alpha_{5} \mathrm{LS}_{\mathrm{t}}+\alpha_{6} \mathrm{MI}_{\mathrm{t}}+\mathrm{e}
$$

Equation (4) refers to Ghana

\section{Model 3}

$$
\mathrm{GDP}_{\mathrm{tK}}=\alpha_{0}+\alpha_{1} \mathrm{GDP}_{\mathrm{t}-1}+\alpha_{2} \mathrm{MC}_{\mathrm{t}}+\alpha_{3} \mathrm{TVL}_{\mathrm{t}}+\alpha_{4} \mathrm{STO}_{\mathrm{t}}+\alpha_{5} \mathrm{LS}_{\mathrm{t}}+\alpha_{6} \mathrm{MI}_{\mathrm{t}}+\mathrm{e}
$$

Equation (5) refers to Kenya

In a study by Senbet (2008), which shows that market capitalization and the value of shares traded relative to the size of the economy are the channels through which African Stock Markets influences economic growth, we assumed stock market capitalization as a proxy for stock market indicator and GDP as a proxy for economic growth to conduct the Granger causality test and verify the direction of causality. This we did by relying on two basic equations as given in the models below:

$$
\begin{aligned}
& \mathrm{GDP}_{\mathrm{t}}= \alpha_{0}+\sum_{\mathrm{i}=1}^{\mathrm{n}} \mathrm{a}_{\mathrm{i}} \mathrm{MC}_{\mathrm{t}-1}+\sum_{\mathrm{j}=1}^{\mathrm{n}} \beta_{\mathrm{j}} \mathrm{GDP}_{\mathrm{t}-1}+\mathrm{U}_{1 \mathrm{t}} \\
& \mathrm{MC}_{\mathrm{t}}=\underset{1}{\mathrm{n}}+\underset{\mathrm{i}=1}{\sum} \lambda_{\mathrm{i}} \mathrm{MC}_{\mathrm{t}-1}+\sum_{\mathrm{j}=1} \delta_{j} \mathrm{GDP}_{\mathrm{t}-1}+\mathrm{U}_{2 \mathrm{t}}
\end{aligned}
$$

Where MC is a proxy for the variables of stock market development.

Given our hypothesis that "There is no causality relation between stock market development and economic growth", if $\alpha_{0}=\alpha_{i}=\beta_{j}=0$. The direction of causality link between stock market development and economic growth does not flow from stock market development to economic growth and vise versa if $\alpha_{1}=\lambda_{\mathrm{i}}=\delta_{\mathrm{j}}=0$. The $a$ priori expectations are: $\alpha_{0} \neq 0$ and $\alpha_{i}, \beta_{j}, \lambda_{i}, \delta_{j},>0$. If the a priori signs which indicate the coefficients of the indicators of stock market are positively related to economic growth, it suggests that an increase in these factors will cause the Real GDP to increase which is a proxy for economic growth. GDP is the dependent variable with others as independent variables. Each of these indicators was tested against GDP to capture their individual effect on economic growth and vice versa. We also considered individual indicators of stock market liquidity. The rationale behind adopting disaggregated indicators was to capture the different effects between stock market development and economic growth more feasibly rather than adopting a single indicator that would focus on a single aspect.

The study adopted tests for Stationarity, Cointegration and Granger Causality test. The time series properties of the data were examined by conducting the test for Stationarity and Cointegration. This was done as a pretest for Granger Causality test. "The test for Cointegration should precede tests of causality" (Gujarati, 2003:793); hence, test for 
Cointegration was conducted and also Granger Causality test. The Econometric procedure was conducted using EView 3.1. We estimated the constants of Cointegration using Maximum Likelihood Estimation Technique. We used the Augmented Dickey-Fuller and the Phillip Peron test to determine whether the variables are I (1). The tests for significance of all the parameters were conducted using t-statistics on the first difference. If any of these parameters are not significantly different to zero, the appropriate series (that is, the Independent or the Y series) will be I (1)

The problem of using a pooled data method was that by grouping countries together that are at different stages of financial development, the country specific effects of stock market development on economic growth and vice versa are not addressed. It is well known that Cointegration techniques may not be appropriate when the sample size is too small (Nerayan \& Smyth, 2005; Odhiambo, 2009).

\section{Results}

The data set employed in this study consists of annual data from three African countries - Ghana, Kenya and Nigeria presented in Tables 1, 2, and 3 .

Table 1. Stock market development and economic growth indicators for Ghana from 1993 to 2009

\begin{tabular}{ccccccc}
\hline YEAR & $\begin{array}{c}\text { GDP GROWTH } \\
\text { (ANNUAL } \%)\end{array}$ & $\begin{array}{c}\text { MC } \\
\text { (\% OF } \\
\text { GDP) }\end{array}$ & $\begin{array}{c}\text { STOCK TRADED } \\
\text { (TURNOVER } \\
\text { RATIO \%) }\end{array}$ & $\begin{array}{c}\text { STOCK TRADED } \\
\text { TOTAL VALUE } \% \\
\text { OF GDP) }\end{array}$ & $\begin{array}{c}\text { No. of } \\
\text { LS }\end{array}$ & MI \\
\hline 1993 & 4.9 & 2 & 5 & 0.1 & 15 & 132.9 \\
1994 & 3.3 & 34.3 & 7.5 & 1.4 & 17 & 298.1 \\
1995 & 4.1 & 25.5 & 1.3 & 0.3 & 19 & 316.17 \\
1996 & 4.6 & 21.5 & 1.1 & 0.2 & 21 & 360.76 \\
1997 & 4.2 & 16.5 & 3.7 & 0.7 & 21 & 868.35 \\
1998 & 4.7 & 18.5 & 4.8 & 0.8 & 21 & 511.74 \\
1999 & 4.4 & 11.9 & 2.1 & 0.3 & 22 & 736.16 \\
2000 & 3.7 & 10.1 & 1.4 & 0.2 & 22 & 857.98 \\
2001 & 4 & 9.9 & 2.6 & 0.3 & 22 & 955.95 \\
2002 & 4.5 & 12 & 1.8 & 0.2 & 24 & 1395.31 \\
2003 & 5.2 & 18.7 & 4.2 & 0.6 & 25 & 3553.42 \\
2004 & 5.6 & 29.8 & 3.2 & 0.7 & 29 & 6798.46 \\
2005 & 5.9 & 15.5 & 3.2 & 0.6 & 30 & 4769.02 \\
2006 & 6.4 & 15.9 & 2.1 & 0.3 & 32 & $5,006.02$ \\
2007 & 6.5 & 9.7 & 3.9 & 0.4 & 32 & $6,599.77$ \\
2008 & 8.4 & 11.9 & 5.2 & 0.5 & 35 & $10,431.64$ \\
2009 & 4.7 & 9.6 & 2 & 0.2 & 35 & $5,572.64$ \\
\hline
\end{tabular}

Source: World Bank National Accounts Data, and OECD National Accounts Data Files, World Development Indicators, African Securities Exchange Association Year Book, Ghana Stock Exchange Annual Reports \& Accounts, various years.

Table 2. Stock market development and economic growth indicators for Kenya from 1990 to2009

\begin{tabular}{ccccccc}
\hline YEAR & $\begin{array}{c}\text { GDP GROWTH } \\
\text { (ANNUAL \%) }\end{array}$ & $\begin{array}{c}\text { MC } \\
\text { (\% OF } \\
\text { GDP) }\end{array}$ & $\begin{array}{c}\text { STOCK TRADED } \\
\text { TURNOVER } \\
\text { RATIO }(\%)\end{array}$ & $\begin{array}{c}\text { STOCK TRADED } \\
\text { TOTAL VALUE }(\% \\
\text { OF GDP) }\end{array}$ & $\begin{array}{c}\text { No. of } \\
\text { LS }\end{array}$ & MI \\
\hline 1990 & 4.2 & 5.3 & 2.1 & 0.1 & 54 & 915 \\
1991 & 1.4 & 5.6 & 2.4 & 0.1 & 53 & 958 \\
1992 & -0.8 & 7.7 & 2.2 & 0.1 & 57 & 1,167 \\
1993 & 0.4 & 18.4 & 1.6 & 0.2 & 56 & 2,514 \\
1994 & 2.6 & 43.1 & 3 & 0.9 & 56 & 4,559 \\
1995 & 4.4 & 20.8 & 2.6 & 0.7 & 56 & 3,469 \\
1996 & 4.1 & 15.3 & 3.6 & 0.6 & 56 & 3,114 \\
1997 & 0.5 & 13.9 & 5.8 & 0.8 & 58 & 3,115 \\
1998 & 3.3 & 14.4 & 4.1 & 0.6 & 58 & 2,962 \\
1999 & 2.3 & 10.9 & 4.3 & 0.6 & 57 & 2,303 \\
2000 & 0.6 & 10.1 & 3.5 & 0.4 & 57 & 1,913 \\
2001 & 3.8 & 8.1 & 3.4 & 0.3 & 57 & 1355
\end{tabular}




\begin{tabular}{lcccccc}
2002 & 0.5 & 10.8 & 2.9 & 0.3 & 57 & 1,087 \\
2003 & 2.9 & 28 & 7.5 & 1.4 & 51 & 1,935 \\
2004 & 5.1 & 24.2 & 8.5 & 2.1 & 47 & 2,640 \\
2005 & 5.9 & 34.2 & 9.8 & 2.7 & 47 & 3,972 \\
2006 & 6.3 & 50.6 & 14.6 & 5.8 & 51 & 4,260 \\
2007 & 7 & 49.3 & 10.6 & 4.9 & 51 & 5,146 \\
2008 & 1.6 & 36.4 & 11.8 & 4.8 & 53 & 5,185 \\
2009 & 2.6 & 36.6 & 4.6 & 1.7 & 55 & 3,294 \\
\hline
\end{tabular}

Source: World Bank National Accounts Data, and OECD National Accounts Data Files, World Development Indicators, African Securities Exchange Association Year Book, Nairobi Stock Exchange Annual Reports \& Accounts, various years.

Table 3. Stock market development and economic growth indicators for Nigeria from 1990 to 2009

\begin{tabular}{ccccccc}
\hline YEAR & $\begin{array}{c}\text { GDP GROWTH } \\
\text { (ANNUAL })\end{array}$ & $\begin{array}{c}\text { MC } \\
(\% \text { OF } \\
\text { GDP) }\end{array}$ & $\begin{array}{c}\text { STOCK TRADED } \\
\text { TURNOVER } \\
\text { RATIO }(\%)\end{array}$ & $\begin{array}{c}\text { STOCK TRADED } \\
\text { TOTAL VALUE } \% \\
\text { OF GDP) }\end{array}$ & $\begin{array}{c}\text { No. of } \\
\text { LS }\end{array}$ & MI \\
\hline 1989 & 7.2 & 4.2 & 0.4 & 0 & 111 & 325.3 \\
1990 & 8.2 & 4.8 & 0.9 & 0 & 131 & 513.8 \\
1991 & 4.8 & 6.9 & 0.6 & 0 & 142 & 783 \\
1992 & 2.9 & 3.7 & 0.9 & 0 & 153 & $1,107.60$ \\
1993 & 2.2 & 4.8 & 0.9 & 0 & 174 & $1,548.80$ \\
1994 & 0.1 & 11.5 & 1 & 0.1 & 177 & 2,205 \\
1995 & 2.5 & 7.2 & 0.6 & 0 & 181 & $5,092.20$ \\
1996 & 4.3 & 10.1 & 2.6 & 0.2 & 183 & $6,992.10$ \\
1997 & 2.7 & 10.1 & 3.7 & 0.4 & 182 & $6,440.50$ \\
1998 & 1.9 & 9 & 4.9 & 0.5 & 186 & 5,716 \\
1999 & 1.1 & 8.5 & 5 & 0.4 & 194 & $5,266.40$ \\
2000 & 5.4 & 9.2 & 7.3 & 0.6 & 195 & $8,111.00$ \\
2001 & 3.1 & 11.3 & 10.3 & 1 & 194 & $10,963.10$ \\
2002 & 1.5 & 9.7 & 8.5 & 0.8 & 195 & $12,137.70$ \\
2003 & 10.3 & 14 & 11.3 & 1.3 & 200 & $20,128.90$ \\
2004 & 10.6 & 16.5 & 13.9 & 1.9 & 207 & $23,844.50$ \\
2005 & 5.4 & 17.2 & 11.5 & 1.7 & 214 & $24,085.80$ \\
2006 & 6.2 & 22.3 & 13.6 & 2.4 & 202 & $33,189.30$ \\
2007 & 6.4 & 52 & 28.2 & 10.1 & 212 & $57,990.22$ \\
2008 & 6 & 24 & 29.3 & 9.6 & 213 & $31,450.78$ \\
2009 & 5.6 & 19.3 & 11 & 2.6 & 214 & $26,927.65$ \\
\hline
\end{tabular}

Source: World Bank National Accounts Data, and OECD National Accounts Data Files, World Development Indicators, African Securities Exchange Association Year Book, Nigerian Stock Exchange Annual Reports \& Accounts, various years.

Unit Root Tests: The null hypothesis of a unit root is not rejected for any of the variables (i.e. all the series are non-stationary at level in Table 4). However, each of the series was stationary in first difference, so all the variables are integrated of order one (I (1)). The time series were made $\mathrm{I}(0)$ or stationary by taking their first differences.

Table 4. Results of the unit root tests

\begin{tabular}{|c|c|c|c|c|c|c|}
\hline Countries & Variables & Lag & $\mathrm{ADF}$ & PP & $\begin{array}{ll}\text { Order } & \text { of } \\
\text { Integration } & \\
\end{array}$ & Remarks \\
\hline \multicolumn{7}{|l|}{ Ghana } \\
\hline & DY & 2 & & $-4.4741 * *$ & $\mathrm{I}(0)$ & Stationary \\
\hline & DTR & 2 & & $-5.1739 * * *$ & $\mathrm{I}(0)$ & Stationary \\
\hline & DVT & 2 & $-5.5238 * * *$ & & $\mathrm{I}(0)$ & Stationary \\
\hline & DLS & 2 & & $-4.1513 * *$ & $\mathrm{I}(0)$ & Stationary \\
\hline \multicolumn{6}{|l|}{ Kenya } & Stationary \\
\hline & $\begin{array}{l}\text { DY } \\
\text { DMC }\end{array}$ & $\begin{array}{l}2 \\
2\end{array}$ & & $\begin{array}{l}-5.3684 * * * \\
-4.0495 * *\end{array}$ & $\begin{array}{l}\mathrm{I}(0) \\
\mathrm{I}(0)\end{array}$ & $\begin{array}{l}\text { Stationary } \\
\text { Stationary }\end{array}$ \\
\hline
\end{tabular}




\begin{tabular}{|c|c|c|c|c|c|c|}
\hline & DTR & 2 & & $-4.3011 * *$ & $\mathrm{I}(0)$ & Stationary \\
\hline & DLS & 3 & & $-6.1823 * * *$ & $\mathrm{I}(0)$ & Stationary \\
\hline & DY & 2 & & $-5.0111 * * *$ & $\mathrm{I}(0)$ & Stationary \\
\hline & DMC & 2 & & $-6.0692 * * *$ & $\mathrm{I}(0)$ & Stationary \\
\hline & DVT & 2 & $-6.6681 * * *$ & & $\mathrm{I}(0)$ & Stationary \\
\hline & DLS & 2 & & $-4.7497 * * *$ & $\mathrm{I}(0)$ & Stationary \\
\hline & DMI & & & $-5.0105^{* * *}$ & $\mathrm{I}(0)$ & Stationary \\
\hline
\end{tabular}

Source: EView 3.1 Output.

$(* * *),(* *),(*)$ indicate significant at $1 \%, 5 \%$ and $10 \%$ respectively.

$\mathrm{D}$ indicates first differencing.

Cointegration Test Results: The Cointegration tests are carried out based on the Johansen (1992) maximum likelihood framework. This was used to investigate long term relationships between stock market development and economic growth. Any equilibrium relationship among a set of non-stationary variables implies that their stochastic trends must be linked (Enders, 2004), in which case they are said to be cointegrated. As Granger have noted that "A test for Cointegration can be thought of as a pre-test to avoid 'spurious regression' situations" (Granger, 1986:226). The results are presented in Table 5.

Table 5. Results of cointegration tests

\begin{tabular}{|c|c|c|c|c|c|}
\hline Countries & $\begin{array}{l}\text { Hypothesized } \\
\text { No. of CE(s) }\end{array}$ & Eigenvalue & Likelihood Ratio & $\begin{array}{l}5 \text { Percent Critical } \\
\text { Value }\end{array}$ & $\begin{array}{l}1 \text { Percent Critical } \\
\text { Value }\end{array}$ \\
\hline \multicolumn{6}{|l|}{ Ghana } \\
\hline \multicolumn{6}{|c|}{ Series: GDP, LS, STO, TVL. } \\
\hline & None** & 0.961270 & 83.92719 & 47.21 & 54.46 \\
\hline & At most 1 & 0.814222 & 35.15994 & 29.68 & 35.65 \\
\hline & At most 2 & 0.416536 & 9.911895 & 15.41 & 20.04 \\
\hline & At most 3 & 0.114870 & 1.830319 & 3.76 & 6.65 \\
\hline \multicolumn{6}{|l|}{ Kenya } \\
\hline \multicolumn{6}{|c|}{ Series: GDP, LS, MC, STO. } \\
\hline & None** & 0.880956 & 63.28261 & 47.21 & 54.46 \\
\hline & At most 1 & 0.592596 & 24.97395 & 29.68 & 35.65 \\
\hline & At most 2 & 0.268369 & 8.810851 & 15.41 & 20.04 \\
\hline & At most 3 & 0.162231 & 3.186237 & 3.76 & 6.65 \\
\hline \multicolumn{6}{|l|}{ Nigeria } \\
\hline \multicolumn{6}{|c|}{ Series: GDP, LS, MC, MI, STV. } \\
\hline & None** & 0.980553 & 123.5125 & 59.46 & 66.52 \\
\hline & At most 1 & 0.806674 & 48.65087 & 39.89 & 45.58 \\
\hline & At most 2 & 0.444188 & 17.42670 & 24.31 & 29.75 \\
\hline & At most 3 & 0.275310 & 6.267524 & 12.53 & 16.31 \\
\hline & At most 4 & 0.007828 & 0.149321 & 3.84 & 6.51 \\
\hline
\end{tabular}

Source: EView 3.1 Output.

$*(* *)$ denotes rejection of the hypothesis at $5 \%(1 \%)$ significance level

L.R. test indicates 2 cointegrating equation(s) at $5 \%$ significance level for Ghana

L.R. test indicates 1 cointegrating equation(s) at $5 \%$ significance level for Kenya

L.R. test indicates 2 cointegrating equation(s) at $5 \%$ significance level for Nigeria

Critical Values are given by Osterwald-Lenum (1992) not those tabulated in Johansen and Juselius (1990).

The estimated normalized cointegrating vectors was $r=2$ for Ghana, $r=1$ for Kenya, and $r=2$ for Nigeria as reported in the Table 6. In general, these cointegrating vectors do not have direct structural interpretations being arbitrary linear combinations of the underlying structural equilibrium relationships. However, vector 2 clearly links GDP and LS with the same unit coefficients apparent in vector 1 and 2 and also for Kenya and Nigeria at vector 2 and 3 where GDP and LS have the same unit coefficient. For the reported number of cointegrating vectors, hence we reject the null 
hypothesis of no cointegrating vector and accept that there exist a cointegrating relation between LS and GDP and that there is long run relationship between the two variables. The normalized cointegrating equation can be written as:

For Ghana: GDP - 0.012LS - 0.29STO + 13.89TVL - 30.79

For Kenya: GDP $-0.05 \mathrm{LS}+0.03 \mathrm{MC}+0.37 \mathrm{STO}+2.79$

For Nigeria: GDP + 13.49LS - 204.27MC - 0.18MI + 5715.51STV

Table 6. Estimated cointegrating vectors (normalized results based on the Johansen Likelihood Procedure)

\begin{tabular}{llllll}
\hline Countries & Variables & Vector 1 & Vector 2 & Vector 3 & Vector 4 \\
\hline Ghana & & & & & \\
& GDP & 1.000000 & 1.000000 & 1.000000 & \\
& LS & -0.012421 & 1.000000 & 0.000000 & \\
& STO & -0.699771 & -0.703439 & 0.000000 & \\
& TVL & 1.159031 & 1.331509 & 0.897869 & \\
& Log Likelihood & -1.934977 & 10.68905 & 14.72984 & \\
& C & -3.060868 & -3.443394 & -5.482268 & \\
& & & & & \\
& GDP & 1.000000 & 1.000000 & 1.000000 & \\
& LS & -0.054551 & 0.000000 & 0.000000 & \\
& MC & -0.027001 & -0.019563 & 0.000000 & \\
& STO & -0.372162 & -0.355069 & -0.421567 & \\
& Log Likelihood & -159.9265 & -151.8450 & -149.0327 & \\
& C & 2.796392 & -0.430634 & -0.489767 & \\
& & & & & \\
& GDP & 1.000000 & 1.000000 & 1.000000 & 1.000000 \\
& LS & 13.49130 & 0.000000 & 0.000000 & 0.000000 \\
& MC & -204.2669 & 0.140070 & 0.000000 & 0.000000 \\
& MI & -0.178605 & -0.000503 & -0.000263 & 0.000000 \\
& STV & 5715.509 & 2.429255 & -1.185622 & -24.28840 \\
& Log Likelihood & -309.9054 & -294.2933 & -288.7137 & -285.6546 \\
\hline
\end{tabular}

Source: EView 3.1 Output

The results show evidences of cointegrating vector in the three models, two cointegrating vector for Ghana, one for Kenya and two for Nigeria. These show that the stock market growth and economic growth have long-run, or equilibrium relationships as revealed by the cointegrating vectors. It shows that the stock market fluctuations do help to predict the economy fundamentals. The findings are consistent with existing theoretical underpinnings as illustrated by rational expectations hypothesis and wealth effect, it is also in consonance with the findings of Rousseau \& Wachtel (2000), and Adjasi \& Biekpe (2005). To check the stability of our model, we conducted Cumulative Sum of Recursive Residuals (CUSUM). This revealed that all the critical bounds remain within the 5\% significance level.

Granger-Causality Test: The essence of the study is to examine the causal linkage between stock market development and economic growth using data from Ghana, Kenya and Nigeria.

Table 7. Results of granger-causality test

\begin{tabular}{llllll}
\hline Countries & \multicolumn{1}{c}{ Null Hypothesis } & Obs & F-Statistic & Probability & Causality \\
\hline Ghana & & & & & \\
& LS does not Granger Cause GDP & 15 & 2.67264 & 0.11752 & No \\
& GDP does not Granger Cause LS & & 0.05938 & 0.94267 & No \\
& STO does not Granger Cause GDP & 15 & 0.44355 & 0.65379 & No \\
& GDP does not Granger Cause STO & & 1.08538 & 0.37447 & No \\
& TVL does not Granger Cause GDP & 15 & 0.19568 & 0.82535 & No \\
& GDP does not Granger Cause TVL & & 0.18132 & 0.83685 & No \\
& STO does not Granger Cause LS & 15 & 0.68270 & 0.52732 & No \\
& LS does not Granger Cause STO & & 0.80795 & 0.47286 & No \\
TVL does not Granger Cause LS & 15 & 0.58184 & 0.57672 & No \\
& LS does not Granger Cause TVL & & 0.26252 & 0.77425 & No
\end{tabular}


TVL does not Granger Cause STO STO does not Granger Cause TVL

Kenya

LS does not Granger Cause GDP GDP does not Granger Cause LS MC does not Granger Cause GDP GDP does not Granger Cause MC STO does not Granger Cause GDP GDP does not Granger Cause STO MC does not Granger Cause LS LS does not Granger Cause MC STO does not Granger Cause LS LS does not Granger Cause STO STO does not Granger Cause MC MC does not Granger Cause STO

Nigeria

LS does not Granger Cause GDP GDP does not Granger Cause LS MC does not Granger Cause GDP GDP does not Granger Cause MC MI does not Granger Cause GDP GDP does not Granger Cause MI STV does not Granger Cause GDP GDP does not Granger Cause STV MC does not Granger Cause LS LS does not Granger Cause MC MI does not Granger Cause LS LS does not Granger Cause MI STV does not Granger Cause LS LS does not Granger Cause STV
15

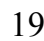

19

19

19

19

19

19

19

19

19

19

19

19
0.01478

2.45607

3.46607

0.36624

5.70614

0.20355

4.43632

4.45081

0.02644

3.57150

0.00869

7.28895

1.68173

0.23102

1.19851

0.75643

0.64546

0.31499

1.22976

0.07261

0.41071

0.27447

0.40437

2.52038

0.97264

3.50626

0.55844

3.62272
0.98535

0.13561

No

No

\subsection{1}

0.55355

0.02957

0.65793

0.05156

0.05099

0.87286

0.07704

0.92690

0.01578

0.21309

0.63727

0.33078

0.48759

0.53934

0.73484

0.32209

0.93031

0.67091

0.76397

0.67091

0.11617

0.40223

0.05828

0.58433

0.05396
Yes

No

Yes

No

Yes

Yes

No

Yes

No

Yes

No

No

No

No

No

No

No

No

No

No

No

No

No

No

No

No

Source: EView 3.1 Output.

From the results in Table 7 the Granger Causality test carried out on GDP and LS are not statistically significant at the 5 percent level, leading to the acceptance of two null hypotheses that LS does not Granger Cause GDP and that GDP does not Granger Cause LS. This suggests that there is no causal link between GDP and LS in Ghana. The probability value of the causal links between GDP and STO were not statistically significant showing that there is also no causal link between GDP and STO and also GDP and TVL. The summary of the general result for Ghana indicate non-existence of causal relationship between the indicators of stock market performance and the proxy for economic growth. This supports the findings of studies by Adjasi (2007) and Sililo (2010). This was found to be in consonance with the Independent Hypothesis which argued that financial and economic growth is not causally related. This is also supported by Mazur and Alexander (2001).

The results obtained from Granger Causality test revealed that there is a causal link between stock market development and economic growth for the Kenyan economy. The F-value for causality running from LS to GDP which is 3.47 is not significant at $5 \%$ level but significant at $10 \%$ level. This shows a weak causality link, but the reverse causality (GDP to LS) was not significant. The F-value for MC to GDP is 5.71; this is statistically significant at $5 \%$ level leading to a rejection of the null hypothesis that MC does not Granger Cause GDP. The F-value for STO to GDP is 4.43 and GDP to STO is 4.45 , this is found to be statistically significant leading to a rejection of the null hypothesis that STO does not Granger Cause GDP and GDP does not Granger Cause STO. We therefore accept bidirectional causality between stock market development and economic growth for the Kenyan economy. This supports Patrick's (1966), Cudi Tuncer \& Alovsat (2001), Mohtadi and Agarwal (2004), Rousseau \& Wachtel (2000) and Filer et al. (1999) findings that there is a two-way causation between financial and economic variables.

The Granger Causality test for the Nigerian economy revealed that there is no causal link between the indicators of stock market performance and the proxy for economic growth at 5\% and $10 \%$ level of significance. All the probability values were not significant, hence the acceptance of the hypothesis; this contradicts the findings of Afees et al. (2010), and confirms but in consonance with the findings of Azarmi et al. (2005). In general, it was found that there was no 
causality linkage between stock market development and economic growth in the Ghanaian and Nigerian economy, but there was a bidirectional causal link between stock market development variables and the variable of economic growth in the Kenyan economy. It therefore behooves the policy makers to strengthen efforts towards improving the capital market.

Analysis of the Regression Results: These are obtained using the Ordinary Least Square (OLS) technique since the variables are stationary and integrated at the same order of integration. The results are in Table 8.

Table 8. The relationships between stock market development and economic growth of Ghana, Kenya and Nigeria

Ghana

\begin{tabular}{|c|c|c|c|c|c|}
\hline $\begin{array}{c}\text { Dependent } \\
\text { Variables }\end{array}$ & Independent Variables & $\begin{array}{l}\text { Estimated } \\
\text { Coefficients }\end{array}$ & Standard Errors & t-statistic & Probability Value \\
\hline \multirow{5}{*}{ GDP } & $\mathrm{C}$ & -0.5304 & 1.0775 & -0.4923 & 0.6314 \\
\hline & LS & 0.1656 & 0.0287 & 5.7666 & 0.0001 \\
\hline & $\mathrm{MC}$ & 0.0633 & 0.0423 & 1.4982 & 0.1599 \\
\hline & STO & 0.6609 & 0.0423 & 1.4982 & 0.1599 \\
\hline & TVL & -3.7822 & 1.5618 & -2.4217 & 0.0322 \\
\hline \multicolumn{6}{|c|}{$\mathrm{R}^{2}=0.77, \mathrm{R}^{2}=0.69, \mathrm{DW}$ stat. $=1.69, \mathrm{~F}-$ stat.$=10.17$} \\
\hline \multicolumn{6}{|l|}{ Kenya } \\
\hline $\begin{array}{c}\text { Dependent } \\
\text { Variables }\end{array}$ & $\begin{array}{l}\text { Independent } \\
\text { Variables }\end{array}$ & $\begin{array}{l}\text { Estimated } \\
\text { Coefficients }\end{array}$ & Standard Errors & $t$-statistic & $\begin{array}{l}\text { Probability } \\
\text { Value }\end{array}$ \\
\hline \multirow[t]{5}{*}{ GDP } & $\mathrm{C}$ & 17.5711 & 9.1904 & 1.9119 & 0.0740 \\
\hline & LS & -0.2893 & 0.1586 & -1.8245 & 0.0868 \\
\hline & $\mathrm{MC}$ & 0.0413 & 0.0403 & 1.0236 & 0.3213 \\
\hline & STO & 0.0318 & 0.1847 & 0.1720 & 0.8656 \\
\hline & \multicolumn{5}{|c|}{$\mathrm{R}^{2}=0.48, \quad \mathrm{R}^{2}=0.38, \mathrm{DW}$ stat. $=1.87, \mathrm{~F}$-stat.$=4.83$} \\
\hline \multicolumn{6}{|c|}{ 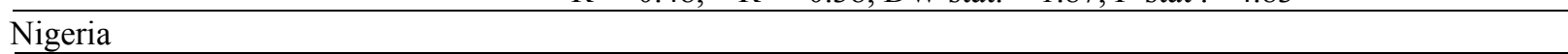 } \\
\hline $\begin{array}{c}\text { Dependent } \\
\text { Variables }\end{array}$ & $\begin{array}{l}\text { Independent } \\
\text { Variables }\end{array}$ & $\begin{array}{l}\text { Estimated } \\
\text { Coefficients }\end{array}$ & Standard Errors & $t$-statistic & $\begin{array}{l}\text { Probability } \\
\text { Value }\end{array}$ \\
\hline \multirow[t]{6}{*}{ GDP } & $\mathrm{C}$ & 17.6941 & 4.3086 & 4.1067 & 0.0008 \\
\hline & LS & -0.0746 & 0.0245 & -3.0464 & 0.0077 \\
\hline & $\mathrm{MC}$ & -0.4711 & 0.1708 & -2.7679 & 0.0137 \\
\hline & MI & 0.0005 & 0.0001 & 4.0747 & 0.0009 \\
\hline & STV & -0.1049 & 0.3564 & -0.2946 & 0.7721 \\
\hline & \multicolumn{5}{|c|}{$\mathrm{R}^{2}=0.57, \mathrm{R}^{2}=0.46, \mathrm{DW}$ stat. $=1.96, \mathrm{~F}$-stat.$=5.28$} \\
\hline
\end{tabular}

Source: EView 3.1 Output.

The results for Ghana revealed that the model explains approximately $77 \%$ of the systematic variation in the level of economic growth in Ghana between 1993 and 2009. These imply that the independent variables included in the model namely: LS, MC, STO and TVL accounted for $77 \%$ of the total adjusted variation in the level of economic growth in Ghana. In relation to statistical significance of each of the explanatory variables LS, STO and TVL were found to be statistically significant at the conventional level of significance (1\%,5\% and 10\%). TVL had a negative effect on GDP. The coefficient of the regression results were found to follow the a priori expectation except TVL that do not exhibit a positive sign indicating a negative effect on GDP. While others impacted positively on GDP. The F-value and Durbin-Watson (DW) statistic further confirm the statistical reliability and desirability of the estimation as there is no evidence of serial correlation

The regression results for the Kenyan economy revealed that $47 \%$ of the systematic variations in GDP were explained by these explanatory variables: LS, MC and STO. This shows the weakness of the model in explaining the relationship between stock market and economic growth in Kenya. This is further confirmed by a low value of F-statistic of 4.83 which is not significant at $1 \%$ level but significant at $5 \%$ level. However, an examination of the t-statistics for the different variables revealed thus: MC, STO and LS had t-value of 1.02, 0.17 and -1.82 that were not significant. The signs show that LS has negative impact on GDP and LS do not conform to the a priori expectations though there is no presence of autocorrelation. The result therefore revealed that in the Kenyan economy stock market has not significantly contributed to the growth of GDP. Hence the call on the part of Capital Market Authority (CMA) to intensify effort to improve the capital market activities. 
The Regression result of Nigeria revealed that the explanatory variables: LS, MC, MI and STV together explained 56\% of the variation in GDP. This does not indicate a very good fit. The F-statistic was found to have weak statistical significance. A Durbin-Watson statistic value of 1.96 shows the absence of serial correlation. The explanatory variables have significant t-values at $1 \%$ level except STV which shows a negative effect on GDP. Only MI conforms to a priori expectation of a positive sign. In general, the analysis revealed that the impact of stock market is not pronounced on the growth of the economy.

The Regression Results of the Pooled Least Square:

Table 9. The regression results of the pooled least square

\begin{tabular}{clllll}
\hline $\begin{array}{c}\text { Dependent } \\
\text { Variables }\end{array}$ & $\begin{array}{l}\text { Independent } \\
\text { Variables }\end{array}$ & $\begin{array}{l}\text { Estimated } \\
\text { Coefficients }\end{array}$ & Standard Errors & $t$-statistic & $\begin{array}{l}\text { Probability } \\
\text { Value }\end{array}$ \\
\hline GDP & C & 3.2649 & 0.8953 & 3.6466 & 0.0007 \\
& MC? & 0.0246 & 0.0369 & 0.6667 & 0.5084 \\
& LS? & -0.0156 & 0.0055 & -2.8194 & 0.0071 \\
& MI? & 0.0001 & $5.26 \mathrm{E}-05$ & 2.4909 & 0.0165 \\
& STO? & 0.3656 & 0.1669 & 2.1893 & 0.0338 \\
& STV & -1.0024 & 0.4486 & -2.2344 & 0.0305 \\
\hline
\end{tabular}

Source: EView 3.1 Output.

The results in table 9 reveal that in the three countries, indicators of stock market performance weakly accounted for its contribution to economic growth. Approximately $37 \%$ of the systematic variations in the three countries GDP put together are explained by the five variables used. All the coefficients of these variables are correctly signed except LS and TVL. The t-values were statistically significant at $5 \%$ level of significance except market capitalization. The F-value of 5.19 is significant at the $1 \%$ and $5 \%$ level of significance. This suggests a linear relationship between the regressors and the regressand. The DW statistic of 1.48 implies some presence of positive serial correlation.

A Cross Section Analysis of the Three Countries: The fixed effect of the cross sectional analysis in Table 10 reveals that the three countries have a common intercept.

Table 10. Relationship between GDP and stock market performance indicators for Ghana, Kenya and Nigeria (1993-2009)

\begin{tabular}{llllll}
\hline $\begin{array}{c}\text { Dependent } \\
\text { Variables }\end{array}$ & $\begin{array}{l}\text { Independent } \\
\text { Variables }\end{array}$ & $\begin{array}{l}\text { Estimated } \\
\text { Coefficients }\end{array}$ & Standard Errors & t-statistic & $\begin{array}{l}\text { Probability } \\
\text { Value }\end{array}$ \\
\hline GDP & & & & \\
& MC? & 0.0011 & 0.0221 & 0.0517 & 0.9590 \\
& LS? & 0.0547 & 0.0433 & 1.2621 & 0.2137 \\
& MI? & 0.0002 & $7.45 \mathrm{E}-05$ & 2.1767 & 0.0350 \\
& STO? & 0.2241 & 0.1144 & 1.9578 & 0.0568 \\
& STV & 0.8517 & 0.3808 & -2.2366 & 0.0306 \\
\hline Fixed Effects & & & & \\
GHA-C & 2.8253 & & & \\
& KEN-C & -0.2359 & $\mathrm{R}^{2}=0.92, \mathrm{R}^{2}=0.91$, DW stat. $=1.65$, \\
NIG-C & -9.4434 & F-stat $=123.41$ & & \\
\hline
\end{tabular}

Source: EView 3.1 Output.

The weighted statistics of the regression results revealed that about $92 \%$ of the systematic variations in GDP were accounted for by the indicators of stock market development of the three countries combined. This shows a highly good fit of the estimated equation, this is further reinforced by an F value of 123.41. This shows that consolidation of African Stock market will enhance its impact on the African economy. The entire variable revealed significant t-value at $5 \%$ and $10 \%$ level except market capitalization and Number of Listed Securities. The DW-statistic of 1.7 tends to show absence of serial correlation. The coefficient of STV reveals a negative impact on GDP.

Discussion of Findings. The results are discussed as follows:

1). That in Ghana and Nigeria, there is no causality link between stock market development and economic growth; but in the Kenyan economy, there is bidirectional causality between stock market developments and economic growth. A possible explanation may be that the stock markets in Ghana and Nigeria do not have adequate representation of the 
major contributors to the GDP such as agriculture and the extractive sector. However, in Kenya, agricultural firms constitute the major drivers of the capital market.

2). In the Kenyan economy where stock market development was found to Granger-cause economic growth, the direction of causality was found to be running from stock market indicators to economic growth and also from the proxy of economic growth to stock market development.

3). In the pooled data, there is a weak relationship between stock market development and economic growth. That is, the combined data of the stock markets of the three economies do not have significant effect on the combined economy. Hence, it may be said that stock markets in West Africa and East Africa in particular, and Africa in general have not contributed significantly to the growth of the African economy.

The implications of the findings of the study is that the supposed effect of the stock markets on the growth of the economies of Ghana and Nigeria has been hampered by the factors mitigating against the ability of these countries stock markets to attract considerable level of investments and maintain investors confidence, especially the delink between the stock market and the sectors that dominate the GDP. It also implied that the pockets of reforms over the years were not religiously followed. The channels for transmission between the surplus unit and the real sector of these economies has suffered regulatory and supervisory bottlenecks (institutional qualities), exposure to external shocks and such menace known to be major obstacles confronting Africa's institutional development.

Overtimes, positive reforms that could lead to growth are always short-lived thereby recording only a short term effect on these economies. Though the stock markets in these economies have witnessed tremendous changes over the years but the effects of these changes are always short lived as factors such as low level of public awareness and participation, failure of corporate governance, market malfeasances and policy inconsistencies still ravage the stock markets of these economies.

\section{Conclusion}

Undoubtedly, the presence of stock market should increase the amount of capital stock available for investment. This is expected to enhance the performance of the economy. However, African stock market has been plagued by a plethora of bottlenecks and drawbacks institutionally, structurally, and otherwise. A skewing phenomenon has been the nature of African stock market and the economy.

In conclusion, the nature of stock markets and the economies in Africa revealed the reasons for non-causal relationships between stock markets and economic growth in Ghana and Nigeria. The problem of African stock markets is the domination by a single sector, and the often monoproduct economy. Often, the stocks of this sector that account for the greater percent of the GDP are not listed in the domestic stock market, hence, a divorce between the actual performance of the stock market and economic growth. In Ghana, only AngloGold Ashanti, accounts for $70 \%$ of market capitalization (Osaze, 2007) while in Nigeria, over $60 \%$ of the total market capitalization is accounted for by the Banking sector. The oil and gas sector of the economy of Nigeria and the agricultural sector (cocoa) of that of Ghana are not in their stock markets.

The following recommendations are made:

The findings are inconsistent with those of previous studies such as Levine (2005) and Afees (2010). This implied that stock markets in Africa are inefficient in allocating resources to the real sectors of the economy for productive ventures that can lead to economic growth. This therefore calls for a much needed effort on the part of policy maker and regulatory bodies to improve the efficiency of the stock markets. The government (policy making body) and regulatory bodies should encourage companies operating in the domestic economy to be listed on the domestic stock exchanges. The regulatory bodies should remove impediments to listing and increase its public awareness campaign through every trading floor of the exchanges and capital trading points.

That the government and regulatory agencies should formulate and implement policies that will ensure relative stability in the bank-based financial sector and market-based stock market of the economy to foster capital formation, increased investment and ensure stability in the financial system.

The government and the self-regulatory organizations should create and ensure strong, more transparent institutional and legal framework and should also encourage investment in human resources to bring about efficiency of the stock exchanges and their auxiliary (support) services in efficiently allocating the available financial resources for investment purpose and also creating the platform that will engender best corporate practice which will result in growing investment, increased confidence in the financial system and further growth of the economy. 
That there should be an improvement in financial infrastructures and increased varieties of financial products and services which has been a major hindrance affecting the pace of investment growth in Africa when compared to developed countries. This is to allow for efficient flow of information and ensure various sources of finance.

Policies and aids should be directed at a more vibrant equity market which is an important engine of economic growth in developing countries. The government should ensure a stable macroeconomic environment for businesses to thrive.

The various economies under study should diversify their economy instead of over reliance on a single sector of the economy and also encourage investment into those sectors of the economy that have direct linkages with economic growth and are considered fundamental to the growth of the economy such as the agricultural sector, construction and manufacturing sector.

Seeing that the higher the level of investment the higher the level of economic growth, keeping cost of doing businesses low and strengthening the infrastructure will increase investment, hence economic growth.

Stock markets in Africa tend to be small and fragmented. Regional integration could contribute to more efficient capital markets; though, there have been limited intra-regional trade, underdeveloped financial infrastructure and lack of regulatory capacities remains major problems. In order to compensate for these shortcomings, regional integration of the stock markets can be useful, particularly in terms of economies of scale. A strong financial institutions and efficient capital market which is essential to increase investment opportunity for both domestic and foreign investors should be encouraged.

\section{References}

Adajaski, C. K.D., \& Biekpe, N. B. (2005). Stock Market Development and Economic Growth: The Case of Selected African Countries. Working Paper, African Development Bank.

Adelegan, O. J. (2003). Capital Market Efficiency and the Effects of Dividend Announcements on Share Prices in Nigeria. African development Review, 15, 218-236. http://dx.doi.org/10.1111/j.1467-8268.2003.00072.x

Adjasi, C. K. D. (2007). Links between Stock Market Development and Key Economic Variables: The Case of Selected Countries. Unpublished D. D. P. Dissertation, University of Stellenbosch, Bellvile.

Afees, A. S., \& Ajide, B. K. (2010). The Stock Market and Economic Growth in Nigeria: An Empirical Investigation. Journal of Economics Theory, 4(2), 65-70. http://dx.doi.org/10.3923/jeth.2010.65.70

African Securities Exchanges Association (ASEA). (2008). Yearbook 2007. Nairobi: African Security Exchanges Association.

African Securities Exchanges Association (ASEA). (2009). Yearbook 2008. Nairobi: African Security Exchanges Association.

African Securities Exchanges Association (ASEA). (2010). Yearbook 2009. Nairobi: African Security Exchanges Association.

Alovsat, M. (1998). Stock Markets and Economic Growth: A Causality Test. An MBA thesis submitted to the Institute of Social Sciences, Istanbul Technical University, Istanbul.

Argrawall R., \& Tuteja, S. K. (2007). Causality between Stock Market Development and Economic Growth: A Case for India. Journal of Management Research, 3(7), 158-168.

Azarmi, T., Lazar, D., \& Jeyapaul, J. (2005). Is the Indian Stock Market A Casino? Journal of Business \& Economics Research, 3(4), 63-72.

Bahadur, S. G. C., \& Neupane, S. (2006). Stock Market and Economic Development: A Causality Test. The Journal of Nepalese Business Studies, 3(1), 36-44.

Beck, T., \& Levine, R. (2001). Stock Markets, Banks and Growth: Correlation or Causality. Policy Research Working Papers 2670, Washington DC: World Bank.

Beck, T., \& Levine, R. (2004). Stock Markets, Banks, and Growth: Panel Evidence. Journal of Banking \& Finance, 28(3), 423-442. http://dx.doi.org/10.1016/S0378-4266(02)00408-9

Bencivenga, V. R., \& Smith, B. (1991). Financial Intermediation and Endogenous Growth. Review of Economic Studies, 195(209).

Capasso, S. (2006). Stock Market Development and Economic Growth. World Institute for Development Economic Research, Research paper NO.2006/102. 
Caporale, G. M., Howells, P., \& Soliman, A. M. (2004). Stock Market Development and Economic Growth: the Causal Linkage. Journal of Economic Development, 29(1).

Cudi Tuncer, G., \& Alovsat, M. (2001). stock markets and Economic Growth: A Causality Test. Institute of Social Science, Istanbul Technical University.

Databank, (2004). African Stock Markets Consolidate Gains, Databank research. Accra: Databank.

Demirgüç-Kunt A., \& Maksimovic V. (1998). Law, Finance, and Firm Growth. Journal of Finance, (53), 2107-2139. http://dx.doi.org/10.1111/0022-1082.00084

Demirguc-Kunt, A., \& Levine, R. (1996a). Stock Market Development and Financial Intermediaries: Stylized Facts. The World Bank Economic Review, 10(2), 291-321. http://dx.doi.org/10.1093/wber/10.2.291

Demirgüç-Kunt, A., \& Levine, R. (1996b). Stock Market, Corporate Finance and Economic Growth: An Overview. The World Bank Review, 10(2), 223-239. http://dx.doi.org/10.1093/wber/10.2.223

Dickey, D. A., \& Fuller, W. A. (1979). Distribution of Estimators for Autocorrelated Time Series with a Unit Root. Journal of the American Statistical Association, 74, 427-31.

Donwa, P., \& Odia, J. (2010). An Empirical Analysis of the Impact of the Nigerian Capital Market on Her Socio-economic Development, J Soc Sci., 24(2), 135-142.

Enders, W. (2004). Applied Econometric Time Series ( $2^{\text {nd }}$ ed.). Singapore: John Willey \& Sons (Asia) Ptc. Ltd.

Engle, R. F., \& Granger, C.W. J. (1987). Cointegration and Error Correction: Representation, Estimation and Testing. Econometrica, 55, 251-276. http://dx.doi.org/10.2307/1913236

Ewah, S. O. E., Esang, E. A., \& Bassey, J. U. (2009). Appraisal of Capital Market Efficiency on Economic Growth in Nigeria. Journal of Business and Management, 4(12) Retrieved from www.ccsenet.org/journal.html

Filer, R., Hanonsek, J., \& Campos, N. (1999). Do Stock Markets Promote Growth? Working Paper No. 267, (September). University of Dar-es-salaam. Economic Research Bureau (ERB), Paper 84.3.

Fuentes, G. (2010). Leading Indicators for the Stock Market. eHow, May 11.

Granger, C. W. J. (1964). Spectral Analysis of Economic Time Series. Princeton: Princeton University Press. In association with M. Hatanaka.

Granger, C. W. J. (1969). Investigating Causal Relations by Econometric Models and Cross-Spectral Methods. Econometrica, 37, 424-438. http://dx.doi.org/10.2307/1912791

Granger, C. W. J. (1986). Developments in the Study of Cointegrated Economic Variables. Oxford Bulletin of Economics and Statistics, 48, 213-28. http://dx.doi.org/10.1111/j.1468-0084.1986.mp48003002.x

Gujarati, D. N. (2003). Basic Econometrics (4 ${ }^{\text {th }}$ ed.). New Delhi: Tata McGraw-Hill Companies Inc.

Johansen, S., \& Jesulius, K. (1990). Maximum Likelihood Estimation and Inference on Cointegration - With Applications to the Demand for Money. Oxford Bulletin of Economics and Statistics, 52, 169-210. http://dx.doi.org/10.1111/j.1468-0084.1990.mp52002003.x

Johansen, S. (1988). Statistical Analysis of Cointegrating Vectors. Journal of Economic Dynamics and Control, 12, 231-28. http://dx.doi.org/10.1016/0165-1889(88)90041-3

Korajczyk, R. (1996). A Measure of Stock Market Integration for Development and Emerging Markets. The World Bank Economic Review, 10(2), 267-89. http://dx.doi.org/10.1093/wber/10.2.267

Levine, R., \& Zervos, A. (1998). Stock Markets, Banks, and Economic Growth. American Economic Review, 88(3), $537-58$.

Levine, R., \& Zervos, S. (1996). Stock Market Development and Long Run Growth. World Bank Economic Review, 10(2). http://dx.doi.org/10.1093/wber/10.2.323

Levine, R., Loayza N., \& Beck T. (2000a). Financial Intermediation and Growth: Causality and Causes. Journal of Monetary Economics, (46), 31-77. http://dx.doi.org/10.1016/S0304-3932(00)00017-9

Levine, R., Loayza N., \& Beck T., (2000b). Finance and the Sources of Growth. Journal of Financial Economics, (58), 261-300.

Levine, R. (1997a). Financial Development and Economic Growth. Journal of Economic Literature, 35(2), 688-727. 
Levine, R. (1997b). Stock Markets, Economic Development and Capital Control Liberalization, Perspective. Investment Company Institute, Occasional papers, 3(5).

MacKinnon, J. J. (1991). Critical Values for Cointegrating Tests. In Engle, R. F. \& Granger C. W. J. (Eds.), Long Run Economic Relations. Oxford University Press.

Mazur, E. M., \& Alexander, R. (2001). Financial Sector Development and Economic Growth in New Zealand. Applied Economics Letter, 8, 545-549. http://dx.doi.org/10.1080/13504850010012974

McKinnon, R. I. (1973). Money and Capital in Economic Development. Washington, DC: Brookings Institution.

Mohtadi, H., \& Agarwal, S. (2004). Stock Market Development and Economic Growth: Evidence from Developing Countries. Department of Economics, University of Wisconsin-Milwaukee, Milwaukee, WI 53201.

Mun, H. W., Siong, E. C., \& Thing, T. C. (2008). Stock Market and Economic Growth in Malaysia: Causality Test. Asian Social Science, 4(4).

N'Zue, F. (2006). Stock Market Development and Economic Growth: Evidence from Cote d' Ivoire. Africa Development Review, 18(1), 123-143. http://dx.doi.org/10.1111/j.1467-8268.2006.00135.x

Narayan, P. K. (2005). The Saving and Investment Nexus for China: Evidence from Cointegration Tests. Applied Economics, (37), 1979-1990. http://dx.doi.org/10.1080/00036840500278103

Narayan, P. K., \& Smyth, R. (2005). Electricity Consumption, Employment and Real Income in Australia: Evidence from Multivariate Granger Causality Tests. Energy Policy, (33), 1109-1116. http://dx.doi.org/10.1016/j.enpol.2003.11.010

Narayan, P. K., \& Smyth, R. (2006). Higher Education, Real Income and Real Investment in China: Evidence From Granger Causality Tests. Education Economics, (14), 107-125. http://dx.doi.org/10.1080/09645290500481931

Narayan, P. K., \& Smyth, R. (2008). Energy Consumption and Real GDP in G7 Countries: New Evidence from Panel Cointegration with Structural Breaks. Energy Economics, (30), 2331-2341. http://dx.doi.org/10.1016/j.eneco.2007.10.006

Nairobi Stock Exchange. (2009). Annual Reports. Nairobi: Nairobi Stock Exchange.

Odhiambo, N. M. (2008). Financial Depth, Savings and Economic Growth in Kenya: A Dynamic Causal Linkage. Economic Modelling, 25(4), 704-713. http://dx.doi.org/10.1016/j.econmod.2007.10.009

Odhiambo, N. M. (2009). Energy Consumption and Economic Growth in Tanzania: An ARDL Bounds Testing Approach. Energy Policy, 37(2). http://dx.doi.org/10.1016/j.enpol.2008.09.077

Odhiambo, N. M. (2010). Stock Market Development and Economic growth in South Africa: AN ARDL-BOUNDS Testing Approach. South Africa: University of South Africa Pretoria.

Ogunkola, E. O., Bankole, S. A., \& Adewuyi, A. O. (2006). An Evaluation of the Impact of Nigeria's Trade and Investment Policy Reforms. Trade Policy Research and Training Programme (TPRTP) Department of Economics, University of Ibadan.

Oke, B. O. (2005). Stock Market Development and Economic Growth in Nigeria: A Causality Test. BabcockJ Manage. Social Sci., 4, 158-170.

Osamwonyi, I. O. (1981). External Reserves Management \& Development: A Case Study of Nigeria (1960-1980). An M.Sc. Thesis submitted to the Department of Economics and Statistics, Faculty of Social Science, University of Benin, Benin-City.

Osamwonyi, I. O. (2005). Capital Market Imperfections and Community Economic development in Nigeria. Being $a$ paper presented at the Academy of Management Nigeria, on the $23^{\text {rd }}$ of November, at Abuja.

Osaze, B. E. (2000). The Nigeria Capital Market in the African and Global Financial System. Benin City, Nigeria: BOFIC Consulting Group Limited.

Osaze, B. E. (2007). Capital Markets: African \& Global. Nigeria: Bookhouse Company.

Osinubi, T. S. (1998). Stock Market Development and Long-run Growth in Nigeria. Unpublished M.Sc. Economics Dissertation, University of Ibadan, Nigeria.

Osinubi, T. S. (2001). Does Stock Market Promote Economic Growth In Nigeria? Nigeria, Oyo State, Ibadan: Department of Economics, Faculty of the Social Sciences, University of Ibadan. 
Phillips, P. C. (1987). Time Series Regressions with a Unit Root. Econometrica, 55, 277-30. http://dx.doi.org/10.2307/1913237

Rioja, F., \& Valev, N. (2004). Finance and the Sources of Growth at Various Stages of Economic Development. Economic Enquiry, 42(1), 127-40. http://dx.doi.org/10.1093/ei/cbh049

Rousseau, P., \& Wachtel, P. (2000). Equity Markets and Growth: Cross-Country Evidence on Timing and Outcomes, 1980-1995. Journal of Banking and Finance, 1933-1957. http://dx.doi.org/10.1016/S0378-4266(99)00123-5

Senbet, L., \& Otchere, I. (2008). Beyond Banking: Developing Markets; African Stock Market. African Finance for the 21st Century High-Level Seminar Organized by the IMF Institute in Collaboration with the Joint Africa Institute, Tunis, Tunisia, March 4-5.

Sililo, M. (2010). Stock Market Development And Economic Growth: A Case for Zambia. Research Report Presented in Partial Fulfillment of the Requirements for the Degree of Masters of Business Administration at the University of Stellenbosch.

Singh, A. (1997, May). Stock Market, Financial Liberalization and Economic development. Economic Journal, 107, 771-82. http://dx.doi.org/10.1111/j.1468-0297.1997.tb00042.x

The Nigerian Stock Exchange, (2009). Annual Report. Lagos: The Nigerian Stock Exchange.

The Nigerian Stock Exchange. (2010). The Nigerian Stock Exchange: A review of market performance in 2009 and the outlook for 2010. Lagos: The Nigerian Stock Exchange.

Todaro, M. P., \& Smith C. S. (2009). Economic development (10th ed.). England, Pearson Education Limited.

United Nations Economic Commission for Africa (UNECA). (2006). Economic Report on Africa.

World Bank. (2006). Private Sector Development Blog: A Market Approach to Development Thinking.

Yartey, C. A., \& Adjasi C. K. (2007). Stock Market Development in Sub-Saharan Africa: Critical Issues and Challenges. IMF Working Paper 07/209. Washington DC: International Monetary Fund. 